\title{
Calcifying fibrous tumor of axillary region
}

\section{Olfa El Amine El Hadj', Leila Bouhajja1, Aida Goucha1, Jameleddine Ben Hassouna², Ahmed El May', Amor Gamoudi'}

${ }^{1}$ Department of Pathology, Carcinological Institute Salah Azaiez, Tunis, Tunisia, ${ }^{2}$ Department of Carcinological Surgery, Carcinological Institute Salah Azaiez, Tunis, Tunisia

Corresponding author: Dr. Olfa El Amine El Hadj, E-mail: olfaelamine@yahoo.fr

Sir,

We report a 17 year-old woman who presented with a l-year history of left axillary palpable mass. At physical examination the lesion was firm, lipomatous. The breast ultrasonography showed a left voluminous axillary mass, measuring $54 \mathrm{~mm}$, hyperechoic and ill limited. A surgical resection of the mass was performed. Grossly, it was a white firm well-circumscribed and lobed mass measuring 15x10x6 cm. Histological examination showed a benign mesenchymal tumor. It consisted of abundant fibrosis with hyalinised vessels, containing mononuclear infiltrate and foci of psammomatous calcifications (Fig. 1). Lymphoid follicles were noted around vessels and psammomas (Fig. 2). The tumor did not show any features of malignancy. Immunohistochemically, the spindle cells were vimentin positive (Fig. 3) and vessels showed CD34 positivity. These features confirmed the diagnosis of Calcifying fibrous tumors. At 4 years of follow-up, the patient was asymptomatic and there was no recurrence.

The patient's informed consent was obtained.

Prior to the study, patient gave written consent to the examination and biopsy after having been informed about the procedure.

Calcifying fibrous tumor (CFT) is a rare, usually solitary, benign tumor of uncertain etiology. The most common sites are the soft tissues of the extremities, pleura, or peritoneum [1]. It usually affects children and young adults, and it is composed of hyalinized fibrous tissue with dispersed bland fibroblastic spindled cells, scattered psammomatous, and/or dystrophic

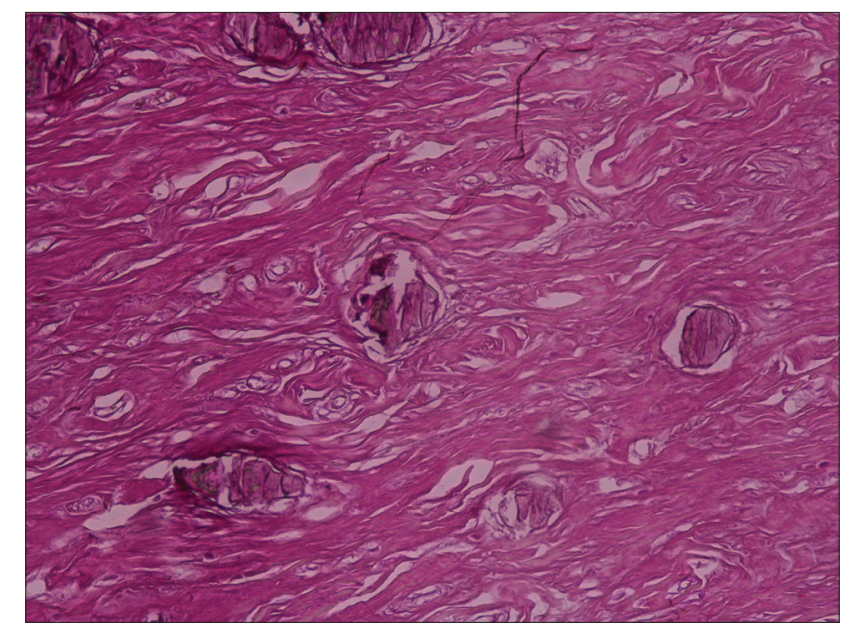

Figure 1: Tumor composed of abundant fibrosis with hyalinised vessels, containing mononuclear infiltrate and foci of psammomatous calcifications.

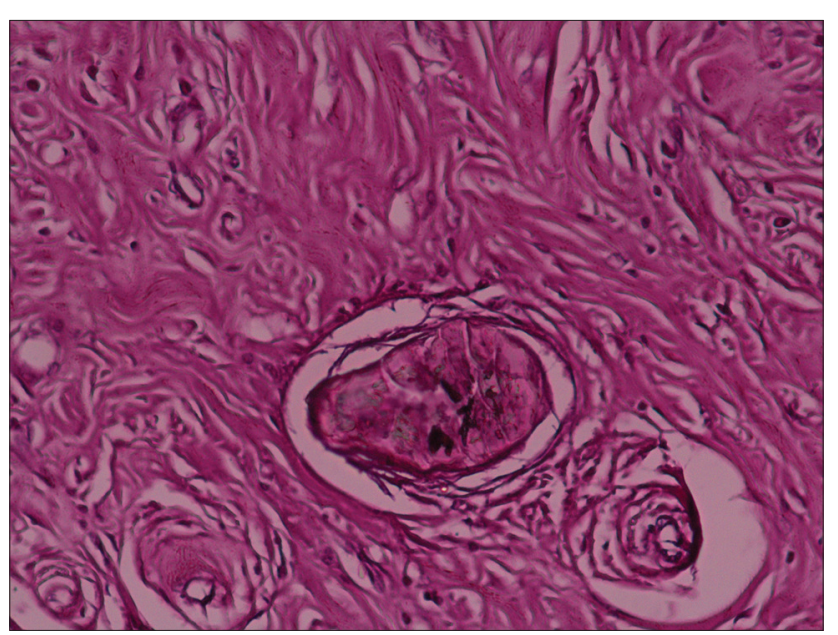

Figure 2: Lymphoid follicles were noted around vessels and psammomas.

calcifications, and variably prominent mononuclear inflammatory infiltrate [2]. Macroscopically, CFT is

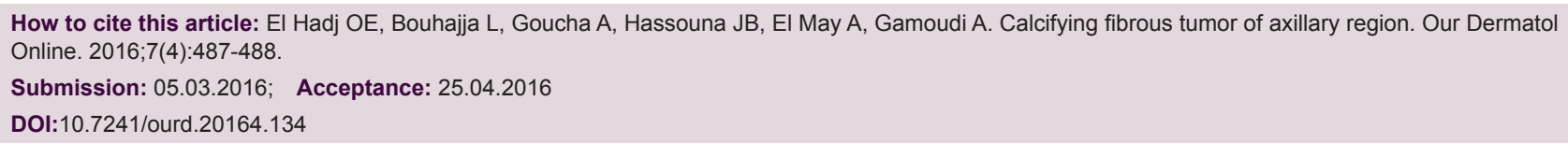




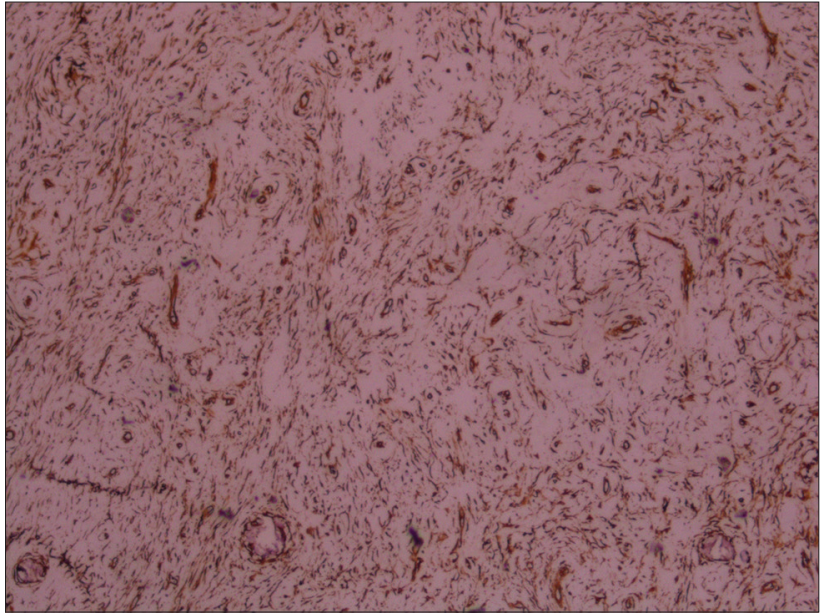

Figure 3: Spindle cells showing strong expression of vimentin.

well circumscribed and unencapsulated. Its diameter ranges from 1 to $15 \mathrm{~cm}$. Their etiopathogenesis has not been fully clarified yet. However, in the literature, there are cases that may be related to trauma and Castleman's disease [3]. Resection of CFT is usually curative. Local recurrence rate is approximately $10 \%$ [1].

\section{Consent}

The examination of the patient was conducted according to the Declaration of Helsinki principles. Written informed consent was obtained from the patient for publication of this article.

\section{REFERENCES}

1. Giardino AA, Ramaiya NH, Shinagare AB, Jagannathan JP, Stachler MD, Raut CP. Case report: Calcifying fibrous tumor presenting as an asymptomatic pelvic mass. Indian J Radiol Imaging. 2011;21:306-8.

2. Jang KY, Park HS, Moon WS, Lee H, Kim CY. Calcifying fibrous tumor of the stomach: A case report. J Korean Surg Soc. 2012;83:56-9.

3. Gamsizkan M, Yildirim C, Daș K, Günhan Ö. Calcifying Fibrous Tumor: A Case Report Turk Patoloji Derg. 2015;31:141-4.

Copyright by Olfa El Amine El Hadj, et al. This is an open access article distributed under the terms of the Creative Commons Attribution License, which permits unrestricted use, distribution, and reproduction in any medium, provided the original author and source are credited.

Source of Support: Nil, Conflict of Interest: None declared. 